This document has been downloaded from

TamPub - The Institutional Repository of University of Tampere

Post-print

The permanent address of the publication is

http://urn.fi/URN:NBN:fi:uta-201411242342

Author(s): Bäcklund, Pia; Kallio, Kirsi Pauliina; Häkli, Jouni

Residents, customers or citizens? Tracing the idea of youthful

Title: $\quad$ participation in the context of administrative reforms in Finnish public administration

Year: $\quad 2014$

Journal Planning Theory and Practice

Vol and

number:

$15: 3$

Pages: $\quad 311-327$

ISSN: $\quad 1470-000 \mathrm{X}$

Discipline:

Political science; Social and economic geography; Other social sciences

School

/Other Unit: School of Management

Item Type: Journal Article

Language: en

DOI: $\quad$ http://dx.doi.org/10.1080/14649357.2014.929726

URN: $\quad$ URN:NBN:fi:uta-201411242342

All material supplied via TamPub is protected by copyright and other intellectual property rights, and duplication or sale of all part of any of the repository collections is not permitted, except that material may be duplicated by you for your research use or educational purposes in electronic or print form. You must obtain permission for any other use. Electronic or print copies may not be offered, whether for sale or otherwise to anyone who is not an authorized user. 


\title{
Residents, customers or citizens? Tracing the idea of youthful participation in the context of administrative reforms in Finnish public administration
}

Bäcklund, Pia \& Kallio, Kirsi Pauliina \& Häkli, Jouni

\begin{abstract}
In parallel with developing participatory policies, public administration in Finland and elsewhere has undergone constitutive administrative reform. By analysing policy documents and civil servants' experiences, we ask how meta-level administrative steering modes manifest themselves in the motives and goals set for participation and what kinds of political agencies they allow for children and young people who play a pivotal role in the future shape of democracy. We conclude that coexisting different steering modes produce different practical solutions that define the content of "citizenship" in different ways. What is essential is the reflectivity concerning whether one or another steering mode dominates participation policy, and with what consequences.
\end{abstract}

Keywords: civic participation, youthful participation, administrative reforms, rationality of public administration 

use the original.

\section{Residents, customers or citizens? Tracing the idea of youthful participation in the context of administrative reforms in Finnish public administration}

\section{Participation policies in the context of administrative reforms}

For decades, civic participation and social justice have been constant themes in critical planning studies (e.g. Forester, 1989; Healey, 1997; Hillier, 2002; Innes \& Booher, 2010; Jacobs, 1961). Since participation entails profound issues of human subjectivity and selfdetermination, it has also been studied in many other disciplines and with multiple approaches (e.g. Barnes, Newman, Knops \& Sullivan, 2003; Douglass \& Friedmann, 1998; Silver, Scott \& Kazepov, 2010; in Finland e.g. Bäcklund, Häkli \& Schulman, 2002). In general, civic participation has become a buzzword in the rhetoric of public administration (Cornwall, 2008; Delvaux \& Schoenaers, 2012; Innes \& Booher, 2004; Leal, 2007; Silver et al., 2010).

However, participation is not just about rhetoric as for example in Finland the legislation increasingly obligates public institutions to arrange opportunities for participation (e.g. Constitution, Municipal Act, Land Use and Building Act, Youth Act). In parallel with developing participation methods, public administrations in Finland and elsewhere have undergone sizeable and constitutive administrative reforms with diverse ideological underpinnings (Beveridge, 2012; Hajer, 2009; Kronsell \& Bäckstrand, 2010; Mäntysalo \& Saglie, 2010; Miller \& Rose, 2008; Sager, 2009). These have not replaced old steering approaches as a whole, but rather they provide new additions to the palette. Since administrative reforms rarely affect all of the adjoining practices, even conflicting systems and rationalities appear (e.g. Bäcklund \& Mäntysalo, 2010; Hajer, 2009; Hiironniemi, 2005; Sager, 2009). This development may lead to 
Practice 15:3, 311-327, doi:10.1080/14649357.2014.929726. For citation, please use the original.

“institutional ambiguity” or an “institutional void” (Hajer, 2003, 2004), situations in which the practices and power relations of politico-administrative processes are obscured (e.g. also Beveridge, 2012; Lester \& Reckhow, 2012). It has been argued that administrative reforms may thus have a much larger impact on the future of civic participation and democracy than specific projects aiming at improving participation and democratic practices (e.g. Aberbach \& Christensen, 2005; Hirst, 2000; Mäntysalo \& Saglie, 2010; Skelcher \& Torfing, 2010; Torfing, Sœrensen \& Fotel, 2009).

In this article, we take part in the discussion on how to best conceive of the rationality of public administration in the context of civic participation (e.g. Alexander, 2001; Bäcklund \& Mäntysalo, 2010; Cassia \& Magno, 2011; Forester, 1984, 1989, 2012; Flyvbjerg, 2004; Freeman \& Aitken-Rose, 2005; Olson \& Hysing, 2012; Sager, 2009). We find that to avoid naïve interpretations, participation should be approached from the points of view of the inhabitants' own lifeworlds and their general motives in different place-based situations (e.g. Davoudi \& Cowie, 2013; Lawless \& Pearson, 2012; Leino, 2012). However, we also hold that an understanding of the reality of planning and decision making - as it is construed by the actors of public administration - is equally vital (e.g. Flyvbjerg, 2004; Forester, 2012; Häkli, 2009; Olson \& Hysing, 2012; Sager, 2009). In line with Michel Foucault (1972; also Flyvbjerg, 2004; Forester, 2012; Wagenaar, Cook \& Noam, 2003; Wagenaar, 2011), we see that making visible the "mentality" of government together with its accompanying everyday practices is a profound part of societal self-understanding.

By analysing policy documents and civil servants' experiences and interpretations concerning current participation policies, we ask 1) how meta-level steering modes inform the ways civic participation is organized in the Finnish public administration, 2) how they manifest themselves in the motives and goals set for 
Practice 15:3, 311-327, doi:10.1080/14649357.2014.929726. For citation, please use the original.

participation, and in the roles and agencies they allow for children and young people, and 3) how the principles of civic participation are reflected on by civil servants responsible for participatory policies and practices.

We focus specifically on interpretations concerning children and young people's participation, since we see that the future shape of democracy is fundamentally conditioned by the scope of political agencies afforded to children and young people by the present participation practices, and that different administrative steering modes have a central role in framing and shaping these practices. Moreover, the legislative obligations for arranging participation for children and young people are particularly strong in Finnish public administration, which means that these issues cannot be overlooked (Kallio \& Häkli, 2011a). Existing practices will be continued and new ones developed and introduced in better or worse forms, and in this regard we see that the "political" in administrative practices appears also as an aspiration to weigh different practices, goals and solutions (e.g. Campbell, 2012; Forester, 2013; Sager, 2009).

Our article is based on three research projects funded by the Academy of Finland: Local political agency and networks of governance (SA253845), Political presence as a right of the child (SA258341) and Preventing children's marginalisation through place-based participation (SA134949), the theoretical approaches of which we bring together in this article. First we discuss briefly the child and youth policy developments in Finland and elsewhere to provide contextual background to our empirical analysis. Second, we present the meta-level steering modes that have been recognized in the Finnish public administration and our analytical tool based on them. Third, we portray our study design, data and methods, before turning to the empirical analysis. Finally, we present our findings and crystallize the results in the concluding section. 
Practice 15:3, 311-327, doi:10.1080/14649357.2014.929726. For citation, please use the original.

\section{Starting points for analysing children and young people's participation policy}

Participation has become a major child and youth policy issue around the world in the past 25 years. The widespread interest in children and young people's potential to partake in public planning and decision making has been invoked by the United Nations Convention on the Rights of the Child (UNCRC) that encourages children's voices to be heard in all matters that concern them (Kallio, 2012b; Kallio \& Häkli, 2014, cf. Larkins, 2013; Tisdall et al., 2006). Finland was amongst the first countries to ratify the UNCRC, in 1991. During the 2000s, the national legislation underwent a major reformation, resulting most importantly in the Youth Act (2006) and the Child Welfare Act (2007), which set the basic parameters for the involvement of children and young people. Obliged by them, the state outlines a new Child and Youth Policy Programme every four years, and municipalities create and constantly update their Child Welfare Plans and variably structured child and youth policy strategies.

The current legislative climate in Finland implies that even though adults are legally responsible for children and young people's well-being, children and youth should be considered as full members of their communities (Kallio and Häkli 2011a). In the name of equality, opportunities to express opinions should not be limited on the basis of age. In this context, children and young people face questions similar to adults: what are their initial possibilities to participate in the issues important to them and express views in a way which is feasible to them? These have been considered to be profound questions defining citizenship, even more than the actual influence these views may have in policy making and politics (e.g. Rosanvallon, 2008). We use the concept of political agency to refer to the above-mentioned possibilities for the children and young people to "act out” their citizenship in ways suitable for them (cf. Kallio, 2012a, 2014; Kallio \& Häkli, 2011b; Kallio et al., forthcoming). 

use the original.

Rising to the challenge to hear children and young people's "voice” in matters concerning them, civil servants are forced to generate empowering practices to enable youthful participation. Adding to the complexity of this work, it is carried out under continuous administrative reform. By defining the most suitable roles, forms, matters, contexts and aims of youthful participation, the administrative strategies and plans of action come to suggest, more or less explicitly, what kind of “citizenship” is desirable at the present and what kind of future citizenship children and young people are being raised into. By analysing our data, we try to make visible how current participation policy defines the starting points of citizenship and creates preconditions for different participation practices, as well as legitimizing them, and how these definitions reflect different administrative steering modes. Since the same politico-administrative processes (based on representative democracy) frame adults' and children and young people's issues, they present the same questions about whether there even is a feasible place for experiential knowledge in these processes.

\section{Meta-level steering modes in Finnish public administration and the idea of participation}

Western democracies share many development trends in public administration, such as multilevel and multi-actor network governance, dismantling of bureaucratic practices, and fortification of neo-liberalist thought in guiding practical applications (e.g. Beveridge, 2012; Bäcklund, 2007; Faludi, 2012; Hajer, 2009; Lester \& Reckhow, 2012; Miller \& Rose, 2008; Sager, 2009; Sam \& Scherer, 2006). These general and global developments always interact with the local politico-administrative context with its own histories. Therefore, the local planning and policymaking context is always a mixture of global, state and regional legal and policy frameworks, local planning 
Practice 15:3, 311-327, doi:10.1080/14649357.2014.929726. For citation, please use the original.

cultures and place-bound specificities (e.g. Friedman, 2005; Häkli \& Kallio, 2014a; Mäntysalo \& Saglie, 2010; Sager, 2009).

In what follows we present three meta-level institutional framings recognizable in the current Finnish public administration. We argue that, despite differences in legal steering and obligations in different branches of administration, these general paradigms of operational principles “trickle down" into the operational policies of individual administrative sectors and frame civil servants' work across sectorial boundaries (e.g. Bäcklund, Jyrämä \& Väisänen, 2010). Hence, they also influence motives and goals for arranging participation, as well as the role of the inhabitant in planning practices, which we discuss in the end of this section.

Meta-level administrative steering modes in Finnish public administration

Despite several waves of administrative reforms, normative steering can still be identified in Finnish public administration (Bäcklund \& Mäntysalo, 2010; Hiironniemi, 2005; Mäntysalo \& Saglie, 2010; Puustinen, 2006). It emphasizes the role of strong legislation and bureaucratic practices in serving the inhabitants on equal and just terms (Callahan, 2007; du Gay, 2000), which has been a central normative issue in the construction of the modern Nordic Welfare State (e.g. Bäcklund \& Mäntysalo, 2010). Normative steering practices are based on the ideals of comprehensive-rationalist (positivist) planning (e.g. Davoudi, 2012). They rest on the notion that the future may be planned and controlled when factual and objective knowledge is available (Alexander, 2001; Bäcklund \& Mäntysalo, 2010; Davoudi, 2012; Schulman, 1990; Taylor, 1998).

The era of comprehensive-rationalist planning has been seen as an explanation as to why direct participation has not had much space in planning practices (e.g. Schulman, 1990). There are two explanatory issues. First, normative steering depends 
Practice 15:3, 311-327, doi:10.1080/14649357.2014.929726. For citation, please use the original.

on the idea of representation whereby elected officials communicate the inhabitants' views into planning and decision making, and civil servants attempt to find the best available solutions, guided by what is conceived as objective expert knowledge. Second, it is difficult for normative steering and comprehensive-rationalist planning to accept the multilevel politics of planning and planning knowledge. Making the distinction between the inhabitants' subjective opinions and the educated planners' apolitical knowledge is still strongly visible in Finnish planning practices (Bäcklund, 2007; Bäcklund \& Mäntysalo, 2010; Faehnle, Bäcklund \& Tyrväinen, 2011; Puustinen, 2006). For example, Davoudi (2012, p. 434) sees that despite a lengthy and ongoing critical theoretical discussion concerning the nature of knowledge in planning, planning practices based on positivistic approaches are re-establishing their position in public administration, in part fostered by, for example, the climate change debate that emphasizes the importance of objective and apolitical data.

Informational steering practices reflect current trends in public administration in Western democracies related to the adoption of neo-liberalist New Public Management (NPM) principles (Callahan, 2007; Clifford \& Tewdwr-Jones, 2013; Häikiö, 2012; Mäntysalo \& Saglie, 2010; McLaughlin, Osborne \& Ferlies, 2002; Miller \& Rose, 2008; Sager, 2009). This development has been seen to follow on from the demands for austerity, effectiveness and quality control in public sector service production (e.g. Sager, 2009, p. 70). Since the informational steering mode emphasizes continual monitoring and evaluation, the concept "evidence-based" has infiltrated public sector practices and gained a prominent role in operational and economic planning.

However, a profound issue for the informational steering mode in general is the utilization of activity-gauging feedback information (e.g. Sager, 2009). This has been 
Practice 15:3, 311-327, doi:10.1080/14649357.2014.929726. For citation, please use the original.

one of the central challenges in public administration and planning over a long period of time (cf. Feldman \& March, 1981; Lindblom, 1959). It also concerns the importance of knowledge produced by the inhabitants. First, unless the planning and decisionmaking system provides concrete ways in which information can be systematically collected, reliably evaluated, and meaningfully utilized, the information will remain of little significance. Second, participation also challenges the "evidence" of evidencebased planning by emphasizing the subjective experiences of inhabitants. However, inhabitants' experiential knowledge is often "translated" into objective, factual knowledge, for example by utilizing quantitative methods (see, for example, Bamberg, 2013; Brown \& Kyttä, 2014; Faehnle et al., 2011). This way, the information produced by inhabitants is made to fit the idea of what is considered to be valid information in the evidence-based approach. The informational steering mode also emphasizes, more or less explicitly, a private nature for participation (e.g. Aberbach \& Christensen, 2005; Miller \& Rose, 2008). It has been noted that individual expressions without the collective aspects of knowledge formation complicate the creation of agoras of political action (e.g. Sager, 2012, p. 620).

The mode of political steering has gained momentum along with the communicative turn in planning (Agger \& Löfgren, 2008; Forester, 1989, 1993; Healey, 1992, 1997; Innes, 1995; Sager, 1994, 2009), thus increasing demands for inhabitants' political involvement in local government practices and decision making (also Bamberg, 2013; Davoudi, 2012; Davoudi \& Cowie, 2013; Delwaux \& Schoenaers, 2012; Demszky \& Nassehi, 2012; Innes \& Booher, 2004). Political steering - based more on interpretative than the positivist planning tradition (Davoudi, 2012) - emphasizes spatio-temporal, local and personal experiences and interpretations. This alters the conception of what appropriate knowledge is: 
Practice 15:3, 311-327, doi:10.1080/14649357.2014.929726. For citation, please use the original.

"Evidence, or indeed the ensemble of different knowledges, would play an enlightening rather than determining role in the process of plan making. Policy is considered to be informed by, rather than based on, evidence" (Davoudi, 2012, p. 437). Although informational steering, too, aims at attaining the subjective views of the inhabitants, there is a big difference between NPM and the communicative planning idea; for example, Sager (2009, p. 73) argues that “communicative planning opens up the process and welcomes all sincere arguments from involved parties. NPM narrows the public debate, in the sense that cost-effectiveness is given a hegemonic position among the arguments".

However, a society that stresses the importance of recognizing inhabitants’ lifeworlds and everyone's right to participate in ways suitable to oneself, cannot escape the tension between representational and direct democracy: what would be the representative role of the elected representatives (cf. Davoudi \& Cowie, 2013) if the inhabitants chose more often to contact civil servants directly and stop voting? How and by whom would different points of view produced by inhabitants be valued? For example, earlier studies in Finland have shown that the division of labour between the civil servants and elected representatives in gathering and valuing inhabitants' experiential knowledge is often unclear (e.g. Bäcklund, 2007; Puustinen, 2006).

Recognizing and accepting different points of view in principle does not automatically mean accepting or being able to work with those differences in practice. What kinds of planning processes would it take to handle this plurality? On which grounds and by whom are legitimate decisions made? These questions remain profound challenges in the political steering mode. Theoretical discussions suggest various solutions. For example, agonistic democracy theory (Mouffe, 2002, 2013) stresses that there should be increasing possibilities for politicizations, as well as aspiration for a 
Practice 15:3, 311-327, doi:10.1080/14649357.2014.929726. For citation, please use the original.

shift from antagonistic to agonistic confrontations, yet provides few practical solutions.

Deliberative democracy theory, on the other hand, offers mutual dialogue as the solution, but leaves open the issues concerning who are and should be "deliberating" around the mutual "planning table”, how one becomes a “deliberator” (e.g. Davoudi \& Cowie, 2013; Hillier, 2002; Kanninen, Bäcklund \& Mäntysalo, 2013; Lester \& Reckhow, 2012), and how to deal with the unavoidability of the existence of power relations (e.g. Alexander, 2001; Hillier, 2000, 2002; Mouffe, 2013).

Administrative steering modes and the idea of participation: building an analytical tool Based on the above discussion and our earlier and on-going research we have developed an analytical tool for this study (Table 1). Previously, we have studied institutional and civic perspectives, policy rhetoric, strategies and related policy processes of administrative developments pertaining to urban planning, and participation in municipal, national and international contexts (e.g. Häkli, 1998, 2009; Bäcklund, 2007; Bäcklund \& Mäntysalo, 2010; Faehnle et al., 2011; Häkli and Kallio, 2014a, 2014b; Kallio, 2012a, 2012b, 2014; Kallio \& Häkli, 2011a, 2011b, 2014; Kallio et al., forthcoming; Kanninen et al., 2013). The tool is a simplified theoretical construction of how the motive for arranging participation, the goal of participation and the role of the inhabitant are construed in different steering modes. Utilizing our tool, we ask our data, which kinds of administrative rationalities participation discourses are related to, and what feasible ways to participate do they simultaneously define - hence also defining the limits of children and young people's political agency.

In the normative steering mode, we define inhabitants as residents, inhabitants who live in certain administrative territories. This status underlines administrative territories as important parts of the governing system, resonating with discussions 

use the original.

concerning the degree to which they can be seen to define significant places and important issues for inhabitants in general (e.g. Bäcklund, 2007; Hajer, 2003; Kallio et al., forthcoming; Lawless \& Pearson, 2012; Leino \& Laine, 2012). Since normative steering highlights the role of elected representatives in bringing out the inhabitants' point of view and demands depoliticized - expert-based - planning knowledge, there is no specific demand for residents’ direct participation within planning practices. On the other hand, the normative steering mode utilizes bureaucracy and laws for legitimation purposes. Therefore, participation will be arranged if there is a legal obligation for it, and this conformance with the law legitimizes administrative operations (cf. Innes \& Booher, 2010, pp. 203-204; Mäntysalo \& Saglie, 2010; Yetano, Royo, \& Acerete, 2010).

In informational steering, the role of the inhabitant is that of a user of services. In this steering mode, we define inhabitants as customers (cf. Aberbach \& Christensen, 2005; Clifford \& Tewdwr-Jones, 2013; Sager, 2009, 2012). The participatory function linked to the inhabitants' role as customers is acquiring "input" for the purposes of quality control and evaluation of efficiency (e.g. Sager, 2009, p. 71). Methods such as sampling or customer panels may be used for gathering feedback. The inhabitants may have an active role as customers, expressing their views about the quality of services. However, challenges still abide: expression of views may be restricted to offering opinions on predefined issues, the validity of which has already been set (Callahan, 2007; Miller \& Rose, 2008). In addition, an opportunity to give feedback does not implicitly mean there is a possibility to improve the state of the service (e.g. Cassia \& Magno, 2011; Dalehite, 2008). Service providers’ operational and strategic issues, such as the economic framework of the public sector, also condition the scope for improvements. 

use the original.

In the political steering mode, the motive for arranging participation in public administration lies in the need to better transmit the inhabitants' multiple realities into administrative practices and political decision making, understanding plurality. An active civil society may be seen as a profound means of reflection - a mirror - for the actions of public administration. The better the societal complexities are recognized, the more the actors of politico-administrative processes are aware of the lifeworlds their decisions are affecting and the ways in which these decisions are shaping them (e.g. Sager, 2009). This is enabled and fostered by participation policies that are based on a multitude of different and complementary practices that enable political agency for various needs (Kallio et al., forthcoming; Miller \& Rose, 2008; Sager, 2009). In political steering mode we define inhabitants as citizens. This stresses the possibility of people themselves defining both the objects and the methods of participation (Hajer, 2003; Kallio, 2012a; Lawless \& Pearson, 2012; Leino \& Laine, 2012; Rosanvallon, 2008; Sager, 2009). The goal for arranging participation is to enable political communities and to create preconditions for a democratic society. Transparent democratic processes are equally important as outcomes.

\begin{tabular}{|l|l|l|l|}
\hline & $\begin{array}{l}\text { Normative } \\
\text { steering }\end{array}$ & $\begin{array}{l}\text { Informational } \\
\text { steering }\end{array}$ & $\begin{array}{l}\text { Political } \\
\text { steering }\end{array}$ \\
\hline $\begin{array}{l}\text { Motivations to } \\
\text { arrange } \\
\text { participation }\end{array}$ & law obedience & $\begin{array}{l}\text { quality and } \\
\text { efficiency } \\
\text { assessment }\end{array}$ & $\begin{array}{l}\text { understanding } \\
\text { plurality }\end{array}$ \\
\hline $\begin{array}{l}\text { Goal/target of } \\
\text { participation }\end{array}$ & $\begin{array}{l}\text { legitimation of } \\
\text { administrative } \\
\text { processes }\end{array}$ & $\begin{array}{l}\text { attaining feedback } \\
\text { information }\end{array}$ & $\begin{array}{l}\text { enabling political } \\
\text { communities }\end{array}$ \\
\hline Role as inhabitant & resident & customer & citizen \\
\hline
\end{tabular}

Table 1. Administrative steering modes and the idea of participation in public administration 

use the original.

\section{Data and methods}

Our analysis is based on fieldwork that was carried out in 2010-2011. The empirical analysis includes the six largest cities in Finland: Helsinki, Espoo, Tampere, Vantaa, Turku and Oulu. The analysed data comprises the Child Welfare Plans (CWP) and thematic essays written by 17 civil servants.

We chose CWPs as our data in order to attain policy documentation that shares a similar steering/guidance role in all target cities ${ }^{1}$. They are policy documents obliged by the Child Welfare Act (L 417/2007), obligating municipalities to prepare a plan for arranging children and young people’s welfare and protection - including participation as a part of their well-being. CWPs are also pivotal politico-administrative documents for translating strategic goals into practical measures. They have to be approved by the municipal council, and administrative sectors are obligated to report to the council on the implementation of the plan. It is meant to steer all sectors of local administration and is prepared in cooperation between administrative sectors.

There are two specific reasons for concentrating on the interpretations and experiences of civil servants instead of elected representatives. First, a strong legal framework in Finland specifically obligates civil servants to arrange participation and "hear” inhabitants in general. Second, since children and young people do not possess full citizenship with the rights and obligations of the fully empowered adult subject, civil servants employ key positions in defining their participation. The informants were

\footnotetext{
${ }^{1}$ Even though the legislative imperatives for arranging participation are strong for adults and children and young people alike (e.g. Municipal Act, Land Use and Building Act, Youth Act), not many municipalities have separate, council-approved policy documents that bind all administrative sectors, nor personnel responsible for participation in their actual duty. Each municipality has made its own solutions for developing participation practices (see, for example, Bäcklund, 2007; Bäcklund \& Mäntysalo, 2010; Kallio et al., forthcoming).
} 

use the original.

chosen from a group of civil servants with important roles in youthful participation. They are from different administrative sectors (e.g. social services, urban planning, education), and there are several informants from each of the targeted cities (due to research ethics affiliations are not included in the analysis). Potential candidates were contacted personally and asked to present their views (in writing) about four themes: 1) the general situation and meaning of children and young people's participation, 2) appropriate content and forms of participation, 3) the effects of everyday environments on the objects of participation, and 4) the availability and relevance of knowledge concerning participation. These 'essays' were of varying length (from a few lines to over a page per theme), depending on the theme and personal experiences.

The starting point for our analysis is that the rationality of the public sector is profoundly built on the interpretations, actions and ethical choices of actors involved in its practices (Barnes et al., 2003; Campbell, 2012; Forester, 1984, 2013; Hajer \& Wagenaar, 2003; Innes \& Booher, 2010; Portugali, 2008). However, civil servants’ actions are also conditioned by institutional frames that may differ widely from one administrative sector - and one local context (e.g. Healey, 2013) - to another, thus enabling and restricting the powers of the individual actor in varying ways (e.g. Alexander, 2001; Bäcklund et al., 2010; Friedmann, 2005; Mäntysalo \& Saglie, 2010, p. 323; Olson \& Hysing, 2012, p. 267; Sager, 2009). Hence, we position them in a dual role, on the one hand as actualizing general principles, institutional framings and obligations, and on the other hand as active actors with their own interests and interpretations - also concerning the principles, framings and obligations. We share Olson and Hysing’s (2012, also Forester, 1989; Mäntysalo \& Saglie, 2010) view that when a window for action opens, civil servants may attempt to take an active role in affecting the content of the politics that interests them also as individuals. 
Practice 15:3, 311-327, doi:10.1080/14649357.2014.929726. For citation, please use the original.

\section{Tracing the idea of children and young people's participation}

In this chapter we describe the steering mode logic we recognised in our data. In the following section we then deepen our analysis and further discuss how civil servants' critique towards current participation policies and practices for children and young people reflects different steering modes and, more generally, institutional ambiguity inside public administration.

Motives for arranging participation: law obedience, quality assessment or understanding plurality?

The legislative and bureaucratic trend toward fostering youthful participation was clearly visible specifically in all Child Welfare Plans. References were made to, for example, the Child Welfare Act and the Youth Act, as well as to various national-level development projects attempting to advance children and young people’s participation. Despite us not asking about the legislative basis for it, many of the essays highlighted obligations for arranging participation - hearing children and young people: "We have a standing rule concerning the child perspective: It must be considered in all decision making” (essay).

We recognized also the need to monitor the quality of public planning: “Children and young people's voice should be better heard in the planning, development and assessment of their services and environments. They are the best experts in these matters and the information would surely be useful to all quarters" (essay). In the informational steering mode participation has an important role. Ideally, the more information there is, the higher the quality of actions of public administration: "In urban planning our major aim is to create better plans. We collect information from children and youth, and exploit it, for example to enhance traffic safety, to create 

use the original.

comfortable environments, or to maintain the existing good conditions” (essay). In these comments, the motivation for arranging participation is also motivated by the need to respond to user orientation, not just the commitment to fulfil legal obligations.

Many of the essays highlighted the view that the reason for arranging participation should be the recognition of children and young people's multiple lifeworlds and the subsequent improved understanding of their needs. Some of the civil servants deal quite explicitly with the fact that children and young people do not form homogenous groups, following the political steering ideal. In this view, “the challenge is to involve those youth who do not usually participate, and whose opinion would diversify the received message in an important way" (essay). Yet, unless participation practices are reflected upon, the goal of making visible the multiple realities of children and young people may remain unattained (cf. Kallio \& Häkli, 2011b).

\section{Goals of participation: legitimation, feedback or enabling political communities?}

One of the commonly stated goals in our data was the establishment of a representational participation method that can attain children and young people's common will. This we interpret as the need to legitimize the actions taken, informed by the normative steering mode. If legislation obligates children and young people’s voice to be heard, the legitimation of decision making is tied to following the letter of the law: public administration must arrange participation that recognizes their (common) voice.

When the set objective is to fulfil the legal obligation to hear children and young people, and their voice is interpreted as a common expression, creating representative practices in accordance with the administrative territories may be seen as relevant (Kallio \& Häkli, 2011a). Our data concretely depicted how the “common will” can be 
Practice 15:3, 311-327, doi:10.1080/14649357.2014.929726. For citation, please use the original.

constructed from the bottom up, according to the administrative logic: "School councils form a natural link with our District Groups, which have representatives from all schools of the area. We have altogether nine District Groups with about 220 children and young people, between 9 and 18 years of age. Then we have the elected Representatives of the Oulu Youth (ONE), a body of 16-19-year-old people that deals with municipal issues in general, with 21 members and 17 substitutes. They work in close collaboration with the office-holders and the elected representatives” (essay).

This normatively oriented goal becomes understandable through the Finnish administrative tradition and the Nordic Welfare context (e.g. Mäntysalo \& Saglie, 2010). Advancement of “common good” or “common will” has been and still is one of the civil servants' typical tasks, forming a strong undercurrent among the Finnish planning professions (Bäcklund \& Mäntysalo, 2010; Puustinen, 2006; Stenvall, 2000). In this approach disinterest towards participation appears as problematic: "Children and the youth don't find acting as part of a group inviting. Instead, things are done individually, in ways comfortable to oneself. Ideological impoverishment and the lack of appropriate ideals have created a pluralist space where wrong tracks do not exist” (essay).

Various assessment practices pertaining to the informational steering mode have become common on all levels of public administration (c.f. Häikiö, 2010; Miller \& Rose 2008). The CWPs themselves form an example of informational steering, involving the incorporated demand for evaluation, follow-up and reporting. Since they define participation advancement as a central issue of children and young people’s wellbeing, the objectives concerning participation also become followed and evaluated. However, the objectives of youthful participation were not concretized into easily evaluable issues. For example, the objective to "develop the participation of children 

use the original.

and young people in urban planning” (Vantaa CFP 2008, p. 7) does not per se tell us what and how to evaluate. We interpret the very general nature of these objectives as telling of a profound ambiguity regarding what children and young people's participation is about: which issues should be incorporated, which practices should be included, which actions count as results - what kind of feedback is needed. The less precise the objectives are, the easier it is to interpret almost any action as reaching those objectives.

The civil servants' explicated goals related to political steering most vividly when discussing the impact of youthful participation. First, it was suggested that if experiential knowledge is not used in planning and decision making, participation starts resembling a game without goals: "It is essential that we do not create pretend participation, but that children and youth are given real opportunities to influence. We shouldn't just hear them but also take their opinions into account in decision making” (essay). Second, it was recognizable in both the CWPs and the essays that, while assessing the effectiveness of participation is an important point of view, it is equally pertinent to reflect on whether children and young people get positive experiences: “[The meaning of participation is] to offer children and young people a possibility for functioning as active citizens, for social learning, for experiences of involvement and ownership” (essay). In this respect participation is not so much about affecting something but gaining experiences of fully belonging to a society.

Roles as inhabitant: resident, customer or citizen?

In defining the limits of political agency, the analysed Child Welfare Plans point largely at the importance of neighbourhood-grounded, territorial youthful participation. It was seen not only to enable the attainment of the "common voice" of children and young 
Practice 15:3, 311-327, doi:10.1080/14649357.2014.929726. For citation, please use the original.

people, but such participation was proposed also as an important welfare aspect in their lives - under the assumption that taking responsibility for the "territorial common good” is good for them. Placed in such a framework, youthful agency comes close to Barber's (1984) view of communitarian (strong) democracy that links participation with a "social contract" on running mutual affairs. The view that children and young people have their own important role in contributing to this contract as residents was recognizable also in the essays: “Genuine participation expects that children and young people rise to the challenge, that is, deal with their share. It is part of the growth process on their way to active citizenship. To achieve this you must work hard and commit to the common good” (essay).

The view that participation practices that are based on administrative territories and on constructing the common good can function as an education to active citizenship, implies that children and young people are "not-yet-citizens” (Kallio et al., forthcoming, cf. Hart, 2009; Lister, 2007). Political life is seen to belong to the realm of adults, which may be entered at a young age if appropriate education is provided. In Finland, student councils in schools, municipal and national children’s parliaments, and youth forums have been seen as central in democracy education (cf. Democracy Education Report, 2011, p. 5; Kallio \& Häkli, 2011a). These ideals are paraphrased in both the CWPs and the essays, as exemplified by the Vantaa CWP, which states "According to the governmental decree, all education supports the development of active citizenship and provides for preparedness to act in a democratic and equal society” (Vantaa Child Welfare Plan 2008, p. 29), and a thematic essay that conveys: "In schools and kindergartens, it is not primarily about collecting children and young people’s views, but citizenship education.” Without questioning the pertinence of learning democratic practices, we find it equally important to reflect on the 

use the original.

presumptions of the territorial bonds that are embedded in these practices, and who they favour (e.g. Kallio et al., forthcoming).

In our data we also identified a tension between attachments to geographical areas and place-based communities (e.g. neighbourhood, school) and the Internet as a central arena for participation. The latter enables forms of participation that are independent of physical proximity: "Network communities offer the best potential to approach groups and collect opinions” (essay). However, if internet participation is primarily about giving individual feedback on predetermined issues, youthful agency is rendered reactive customership void of communality (e.g. Callahan, 2007; Häikiö, 2010, 2012; Miller \& Rose, 2008; Sager, 2009) - a condition often linked with “weak democracy” (e.g. Barber, 1984).

Normative and informational steering types frame the administrative rhetoric concerning the content of political agency in the CWPs. Some thematic essays, instead, point also toward ideals more related to political steering. Here the children and young peoples' role is that of a citizen, influencing both the form and the content of participation. Some civil servants highlight that children and young people should be seen as citizens right now, not only in the future: "Why is this so difficult? To me it seems that it is all about attitude; children and young people are not respected but placed on a lower level in their 'workplaces', the kindergarten and the school”' (essay). Simultaneously, the essays expressed a worry over how the present practices may, despite their good intentions, narrow down some agencies: “I don’t think more than 5 per cent of the high school 9th graders have the capacity for meetings and sitting down at the adults' table. Yet 100 per cent of them have the capacity to act in their own ways, to express concerns and contentment with their own environments” (essay). 

use the original.

\section{Practical challenges for children and young people's participation in relation to meta-level steering modes}

Another objective for our analysis was to recognize the possibilities and challenges the civil servants see in the current participation policies and practices, and how their reflections relate to the different administrative steering modes. We also paid attention to how unified their views were, seeing that this informs us about how the meta-level steering modes become embedded in their work, and also about how the rationality of public administration is concretized in practice.

The civil servants' experiential expressions made visible that even a strong, obligating legal basis does not guarantee that participation will be arranged in practice. This is because the existing legislation concerning youthful participation leaves plenty of room for interpretations regarding how and for which issues it should be arranged, and how the fulfilment of legal obligations should be followed. For example, the Youth Act broadly states: "Young people must have the possibility to participate in the handling of matters concerning local and regional youth work and youth policy. The youth must also be heard in matters pertaining to them.” Many civil servants explicitly stated that in this situation the personal interests of administrative actors matter greatly because "the approach toward child and youth participation has not been specified in any way” (essay). Similar overwhelming inclusiveness and lack of precision can be found in the participatory dictates of the Land Use and Building and Municipal Act (27§), which also risks turning participation into an empty notion (e.g. Leino \& Laine, 2012; Nyman, 2000).

Likewise, the question of who should have the foremost responsibility for organizing participation in public administration surfaced in the essays: "Children and young people's participation is bounced between education and youth sections. Other 

use the original.

departments seem to notice it only on special occasions” (essay). Although the Youth Act and the Child Welfare Act obligate all administrative sectors to arrange this participation, they can only be seen as agents in certain sectors that concentrate on “youthful issues”.

The essays explicated that as the legal obligations are written in general terms, the idea of equal treatment of children and young people is concretized also through interpretations of the responsibilities by, and the motivation and ability of, the individual actors: “Teachers work quite independently so that with a positive attitude and pertinent skills an individual teacher may achieve almost anything. Yet, if the opposite is the case, practically nothing happens” (essay). The idea of equal treatment of children and young people embedded in the normative steering mode may not be fulfilled if the steering legislation leaves too much room for interpretation. In the last instance, individual civil servants may have a significant role in the experiences of youthful citizenship (cf. Barnes et al., 2003; Forester, 1984; Olson \& Hysing, 2012).

In addition, the essays portrayed general difficulties in utilizing the views of children and young people in planning and decision making. Even when youthful participation is seen to provide feasible feedback for developing services and activities, it may have little practical impact: "For years we have employed methods for youth participation but the information and feedback concerning service development has not been utilized to the full extent” (essay). These experiences are an important reminder of the fact that participation is not about methods only, but also the ability and motivation to utilize the experiential knowledge produced by the inhabitants (Bäcklund, 2007; Cassia \& Magno, 2011; Lysgård \& Cruickshank, 2013).

Internet-based participation was portrayed as one alternative to hear children and young people more broadly. Yet we see that even these opportunities involve 

use the original.

democratic risks. When feedback is seen as the central impetus for arranging participation, participation is narrowed down to reactive activities - which in turn may take the form of "the child's voice” in later applications. Children and young people are allowed to express their opinions in certain predetermined issues but not to determine the issues they would like to comment on. Yet, the right to define the issues that need scrutiny or feedback is paramount for the realization of the political citizen (e.g. Rosanvallon, 2008). In this respect, the prospects for children and young people to act on their own grounds were regarded as poor: "One of the biggest problems is that when a young person bears an issue that she or he would like to change, no one has an idea on how to proceed. Through surveys we can enquire about needs, but they are not necessarily important to the young person at that very moment” (essay). Seeing participation as a mere "feedback channel" may also hide the political nature of planning practices, presenting them as primarily technical or communicative acts of government (e.g. Forester, 1993; Hillier, 2003; Kanninen et al., 2013; Mouffe, 2013).

Also, the representative forms of participation that are regarded as an important part of democracy education were critically reflected upon by some civil servants, highlighting that in the worst case these practices reach only a handful of children and young people: "Child and youth parliaments are basically good methods but they are representative, and they do not necessarily have anything to do with genuine participation: five young persons from a school of 800 students participate in the meetings” (essay). This type of participation suits certain children and young people who find legitimate association with politico-administrative structures rewarding and empowering (e.g. Kallio et al., forthcoming). Yet, with a focus on activities restricted to particular forms of action, the scope of such participation remains unavoidably limited. 

use the original.

Being “educated and assisted to participate” implies that the youthful members of the community are expected to "act out” their agency in ways imagined by others (cf. Kallio \& Häkli, 2011b; Cornwall, 2008). In this vein, formal educational participation practices may even hinder children and young people's motivation and possibilities for self-directive active participation in matters important to them: “At the moment, participatory arenas are designed exclusively for those children who acquire special talents, allowing them to act in student councils, youth parliaments and the like. The real question is how to hear the weaker ones, those with poorer social skills” (essay). These comments are connected to an ideal of lived citizenship where people are seen as "active" when participating in their lived communities in ways that need not be taught or assisted by administrative actors (Isin, 2012; Staeheli, 2011).

However, we inferred that there is a strong difficulty associated with taking the plurality of children and young people's lifeworlds as a practical approach to participation, even if the existence of plurality as such was not questioned: "Basically we should always pay specific attention to the marginalizing, the marginalized, and other so-called weak groups. Yet, their problems are probably elsewhere than in participation in planning and decision making. Therefore professionals and advocates from associations can be used to represent them” (essay) (cf. Kallio, 2014). Here, for practical reasons the societal plurality is eventually reduced into representative opinions, so that the voices of the represented can be said to "have become heard". Thus, the issue of representation entangles with fundamental questions concerning the existence of a shared reality and/or its nature (cf. Davoudi 2012). This was a constant issue of demarcation in both datasets. This we interpret as a profound ambiguity concerning the knowledge base of planning and decision-making (Bäcklund, 2007; 

use the original.

Cassia \& Magno, 2011; Dalehite, 2008; Demsky \& Nassehi, 2012; Faehnle et al., 2011; Freeman \& Wass, 2010).

\section{Conclusions: the future of being a citizen?}

We recognized in all of our target cities' CWPs and civil servants' essays some aspects of normative, informational and political steering modes in relation to motives and goals of arranging participation, as well as regarding the contents of political agency. In many of them, all steering modes were present at once. This can be seen as a result of new operational models being layered and intermingled with old ones (e.g. Bäcklund \& Mäntysalo, 2010; Hajer, 2003, 2009; Hajer \& Wagenaar, 2003; Hiironniemi, 2005; Sager, 2009). Hence, with the term democracy of ambiguity we want to highlight a societal situation - framing democracy ideals - in which parallel steering logics and governmental actions operate to create an ambiguous political interface between the inhabitants and the actors of public administration. This may in turn result in ambiguity of democracy - with which we refer to the contiguous and conflicting interpretations of functional democracy and the definition of "citizen” in public administration.

The starting points of all three steering modes may as such be considered as justified: the normative mode stresses legality and forces public administration to arrange participation in general; the informational mode highlights customer feedback and guides public administration to consider the importance of inhabitants' opinions in planning and evaluation; and the political mode emphasizes the right of the inhabitants to define both the objects and forms of participation. What is essential in this respect is the reflectivity of public administration concerning whether one or another steering mode dominates participation policy - and with what kind of consequences. We see that it is of utmost importance, for the future of democracy, to 

use the original.

recognize the roles of political agency that current steering modes enable for children and young people. For example, it is one thing to "learn" how to confront and process different societal viewpoints, and another to give individual feedback to a predefined issue (e.g Aberbach \& Christensen, 2005; Miller \& Rose, 2008; Sager, 2009).

Practices related to a certain steering mode may also implicitly favour certain kinds of children and young people, which was explicitly highlighted by the civil servants. In such situations, promoting civic participation may also prevent some children and young people from seeing themselves as citizens and community members (Kallio \& Häkli, 2014).

The conflicting views on the content of civic participation make visible the fact that public administration does not form a homogenous collective with a unified mind to be discovered (e.g. Barnes et al., 2003; Forester, 1989; Olson \& Hysing, 2012). Instead, constant battles concerning the nature of appropriate participation take place between individual actors and in relation to politico-administrative documents that should steer practices. This was a part of the experiential realities of many of the civil servants in our data. In actual planning practices, then, opposed are not inhabitants' lifeworlds and a monolithic administration but rather inhabitants' wishes related to political agency and administrative actors’ institutionally conditioned assumptions and ideas related to conceptions of what participation should be about. The end result may well be that the content of political agency is defined case by case, based on individual values of the involved administrative actors and also their contextually conditioned possibilities to advance their own views (cf. Olson \& Hysing, 2012; also Forester, 2013; Freeman \& Aitken-Rose, 2005).

We also recognised issues related to general participation discourse. First, the possibility of reaching a common voice was problematized by implications of the 

use the original.

multiplicity of children and young people's lifeworlds and supported by references to the territorially bound representative participation methods. Through these accounts, the fundamental ambiguity concerning whether strengthening participation should be about developing representative democracy methods (normative steering) or about fostering direct democracy, individual expression and political agency (political steering) becomes visible.

Second, civil servants' expressions of their experiences made it clear that irrespective of the objective of arranging participation, the practical challenge is to utilize the information thus gathered (also e.g. Bäcklund, 2007; Davoudi, 2012; Delvaux \& Schoenaers, 2012; Demszky \& Nassehi, 2012; Faehnle et. al, 2011). Our interpretation is that these accounts reflect both the strong role of bureaucratic logic in planning practices and a profound ambiguity related to what is considered legitimate and appropriate knowledge. Overall, citizens’ participation always prompts a question about how much, what kind of and whose experiential knowledge is needed in planning and decision making. The answer is profoundly related to the logic of the dominating meta-level steering mode.

\section{Acknowledgements}

We are grateful to the editors and the anonymous referees for their engaged and helpful comments and suggestions. We also wish to thank the Academy of Finland for financially supporting this work (grants SA 253845, SA258341, SA134949), and the Space and Political Agency Research Group (SPARG) at the University of Tampere for an inspiring research environment. Very special thanks to professors Patsy Healey and Geoff Vigar for their comments to our manuscript, and also for the rest of the GURU staff at Newcastle University for many inspiring discussions during the main author's research visit 2013-2014. 
Practice 15:3, 311-327, doi:10.1080/14649357.2014.929726. For citation, please use the original.

\section{References}

Aberbach, J. D., \& Christensen, T. (2005). Citizens and consumers. An NPM dilemma. Public Management Review, 7(2), 225-245.

Agger, A., \& Löfgren, K. (2008). Democratic Assessment of Collaborative Planning. Planning Theory, 7(2), 145-164.

Alexander, E.R (2001). The Planner-Prince: Interdependence, Rationalities and Postcommunicative Practice. Planning Theory \& Practice, 2(3), 311-324.

Bamberg, J. (2013). Engaging the public with online discussion and spatial annotations: The generation and transformation of public knowledge. Planning Theory \& Practice, 14(1), 39-56.

Barber, B. (1984). Strong Democracy: Participatory Politics for new Age. Berkeley: University of California Press.

Barnes, M., Newman, J., Knops, A., \& Sullivan, H. (2003). Constituting ’The Public” in Public Participation. Public Administration, 81(2), 379-399.

Beveridge, R. (2012). Consultants, depoliticization and arena-shifting in the policy process. Policy Sciences, 45(1), 47-68.

Brown, G., \& Kyttä, M. (2014). Key issues and research priorities for public participation GIS (PPGIS): A synthesis based on empirical research. Applied Geography, 46, 122-136.

Bäcklund, P. (2007). Tietämisen politiikka. Kokemuksellinen tieto kunnan hallinnassa. (Politics of Knowing. Experiential knowledge in City Planning. Dissertation, University Of Helsinki). Helsinki: Helsingin kaupugin tietokeskus.

Bäcklund, P., Häkli, J., \& Schulman, H. (Eds.). (2002). Osalliset ja osaajat. Kansalaiset kaupungin suunnittelussa. (Participants and Experts - Citizens in City Planning). Helsinki: Gaudeamus.

Bäcklund, P., \& Mäntysalo, R. (2010). Agonism and institutional ambiguity: Ideas on democracy and the role of participation in the development of planning theory and practice - the case of Finland. Planning Theory, 9 (4), 333-350.

Bäcklund, P., Jyrämä, A., \& Väisänen, H. (2010). Nyt innovoidaan! Helsingin kaupungin henkilöstön näkemyksiä kehittämistyöstä. [Let's Innovate! Experiences of the 

use the original.

City of Helsinki Personnel on Development Work]. Helsingin kaupungin tietokeskuksen tutkimuksia, 2010(1). Helsinki: Helsingin kaupungin tietokeskus.

Callahan, K. (2007). Citizen Participation: Models and Methods. International Journal of Public Administration, 30(11), 1179-1196.

Campbell, H. (2012). Planning ethics and rediscovering the idea of planning. Planning Theory, 11(4), 379-399.

Cassia, F., \& Magno, F. (2011). Differences between public administrators’ and elected officials' perspectives on the role of the citizen in service quality improvement processes. Total Quality Management, 23(5), 550-559.

Clifford, B., \& Tewdwr-Jones, M. (2013). The Collaborating Planner? Practitioners in the Neoliberal Age. Bristol: Policy Press.

Cornwall, A. (2008). Unpacking ‘Participation’: models, meanings and practices. Community Development Journal, 43(3), 269-283.

Dalehite, E. G. (2008). Determinants of Performance Measurement: An Investigation into the Decision to Conduct Citizen Surveys. Public Administration Review, 68(5), 891-907.

Davoudi, S. (2012). The Legacy of Positivism and the Emergence of Interpretive Tradition in Spatial Planning. Regional Studies, 46(4), 429-441.

Davoudi, S., \& Cowie, P. (2013). Are English Neighbourhood Forums Democratically Legitimate? Planning Theory and Practice, 14(4), 562-566.

Delvaux, B., \& Schoenaers, F. (2012). Knowledge, local actors and public action. Policy and Society, 31, 105-117.

Democracy Education Report (2011). Helsinki: The Finnish National Board of Education.

Demszky, A., \& Nassehi, A. (2012). Perpetual loss and gain: Translation, estrangement and cyclical recurrence of experience based knowledges in public action. Policy and Society, 31, 169-181.

Douglass, M., \& Friedmann, J. (Eds.). (1998). Cities for Citizens. Planning and the Rise of Civil Society in a Global Age. Chichester: John Wiley \& Sons.

du Gay, P. (2000). In Praise on Bureaucracy. Weber. Organization. Ethics. Sage: London. 

use the original.

Faehnle M., Bäcklund P., \& Tyrväinen L. (2011). Looking for the role of nature experiences in planning and decision making: a perspective from the Helsinki Metropolitan Area. Sustainability: Science, Practice \& Policy, 7(1), 45-55.

Faludi, A. (2012). Multi-Level (Territorial) Governance: Three Criticisms. Planning Theory \& Practice, 13(2), 197-211.

Feldman, M. S., \& March, J. G. (1981). Information in Organizations as Signal and Symbol. Administrative Science Quarterly, 26(2), 171-186.

Flyvbjerg, B. (2004). Phronetic planning research: theoretical and methodological reflections. Planning Theory \& Practice, 5(3), 283-306.

Freeman, C., \& Aitken-Rose, E. (2005). Voices of youth - Planning projects with children and young people in New Zealand local government. Town Planning Rewiev, 76 (4), 375-400.

Freeman, C., \& Wass, E. (2010). Planning, Maps, and Children's Lives: A Cautionary Tale. Planning Theory \& Practice, 11(1), 65-88.

Friedmann, J. (2005). Globalization and the emerging culture of planning. Progress in Planning, 64, 183-234.

Forester, J. (1984). Bounded Rationality and the Politics of Muddling Through. Public Administration Review, 44(1), 23-31.

Forester, J. (1989). Planning in the Face of Power. Berkeley, CA: University of California Press.

Forester, J. (1993). Critical theory, public policy, and planning practice. Albany: State University of New York Press.

Forester, J. (2012). Learning to Improve Practice: Lessons from Practice Stories and Practitioners' Own Discourse Analyses (or Why Only the Loons Show Up). Planning Theory \& Practice, 13(1), 11-26.

Forester, J. (2013). On the theory and practice of critical pragmatism: Deliberative practice and creative negotiations. Planning Theory, 12(1), 5-22.

Foucault, M. (1972). The Archeology of Knowledge. London: Tavistock Publications Ltd.

Hajer, M. (2003). Policy without polity? Policy analysis and the institutional void. Policy Sciences, 36, 175-195. 
Practice 15:3, 311-327, doi:10.1080/14649357.2014.929726. For citation, please use the original.

Hajer, M. (2004). Three Dimensions of Deliberative Policy Analysis. The Case of Rebuilding Ground Zero. Paper for Presentation at the 2004 Convention $\mathrm{f}$ the American Political Science Association, Chicago.

Hajer, M. (2009). Authoritative Governance. Policy Making in the Age of Mediatization. Oxford: Oxford University Press.

Hajer, M. \& Wagenaar, H. (2003). Introduction. In H. Maarten \& H. Wagenaar (Eds.), Deliberative Policy Analysis. Understanding Governance in the Network Society, (pp. 1-30). Cambridge: Cambridge University Press.

Hart, S. (2009). The ‘problem’ with youth: young people, citizenship and the community. Citizenship Studies, 13(6), 641-657.

Healey, P. (1992). Planning through debate. Town Planning Review 63(2), 143-162.

Healey, P. (1997). Collaborative Planning: Shaping Places in Fragmented Societies. London: Macmillan.

Healey, P. (2013). Circuits of Knowledge and Techniques: The Transnational Flow of Planning Ideas and Practices. International Journal of Urban and Regional Research, 37(5), 1510-1526.

Hillier, J. (2000). Going round the back? Environment and Planning A 32(1), 33-54.

Hillier, J. (2002). Shadows of Power. London: Routledge.

Hillier, J. (2003). Agonizing Over Consensus: Why Habermasian Ideals cannot be 'Real'. Planning Theory, 2(1), 37-59.

Häikiö, L. (2010). The Diversity of Citizenship and Democracy in Local Public Management Reform. Public Management Review, 12(3), 363-384.

Häikiö, L. (2012). From Innovation to Convention: Legitimate Citizen Participation in Local Governance. Local Government Studies, 38(4), 415-435.

Hiironniemi, S. (2005). Suomen hallinto verkostona - 2000-luvun haasteiden hallintaa. Sisäasiainministeriön julkaisuja ,14/2005. Helsinki: Sisäasiainministeriö.

Hirst, P. (2000). Democracy and Governance. In J. Pierre (Eds.), Debating Governance: Authority, Streering and Democracy, (pp.13-25). Oxford: Oxford University Press.

Häkli, J. (1998). Discourse in the production of political space: Decolonizing the symbolism of provinces in Finland. Political Geography 18(3), 331-363.

Häkli, J. (2009). Boundaries of trust: building a transnational space in Haparanda- 
Tornio. In J. Häkli \& C. Minca (Eds.), Social Capital and Urban Networks of Trust. (pp. 205-232). Aldershot: Ashgate.

Häkli, J., \& Kallio, K.P. (2014a). The global as a field: Children’s rights advocacy as a transnational practice. Environment and Planning D: Society and Space 32(2), 293-309.

Häkli, J., \& Kallio K.P. (2014b). Subject, Action and Polis: Theorizing Political Agency. Progress in Human Geography 38(2), 181-200.

Innes, J. (1995). Planning theory's emerging paradigm: communicative action and interactive practice. Journal of Planning Education and Research 14(4), 183189.

Innes, J., \& Booher, D. (2004). Reframing Participation: Strategies for the $21^{\text {st }}$ Century. Planning Theory \& Practice, 5(4), 419-436.

Innes, J., \& Booher, D. (2010). Planning with complexity: An introduction to collaborative rationality for public policy. New York: Routledge.

Isin, E. (2012). Citizens Without Frontiers. London: Bloomsbury Academic.

Jacobs, J. (1961). The Death and Life of Great American Cities. New York: Random House.

Kallio, K.P. (2012a). Political presence and politics of noise. Space \& Polity, 16 (3), 287302.

Kallio, K.P. (2012b). Desubjugating childhoods by listening to the child's voice and the childhoods at play. ACME: An International E-Journal for Critical Geographies 11(1), 81-109.

Kallio, K.P. (forthcoming 2014). Rethinking spatial socialization as a dynamic and relational process of political becoming. Global Studies of Childhood 4(3), $\mathrm{xx}-\mathrm{xx}$. [accepted]

Kallio, K.P., \& Häkli, J. (2011a). Tracing children’s politics. Political Geography, 30(2), 99-109.

Kallio, K.P., \& Häkli, J. (2011b). Young people’s voiceless politics in the struggle over urban space. GeoJournal ,76, 63-75.

Kallio, K.P., Häkli, J., \& Bäcklund, P. (forthcoming). Lived citizenship as the locus of political agency in participatory policy. Citizenship Studies, xx-xx [accepted]. 
Kallio, K.P., \& Häkli, J. (Eds.). (forthcoming 2014). The Beginning of Politics. London: Routledge/Taylor\&Francis.

Kanninen, V., Bäcklund, P., \& Mäntysalo, R. (2013). Trading zone and the complexity on planning. In A. Balducci \& R. Mäntysalo (Eds.), Urban Planning as a Trading Zone. (pp. 159-178). Dordrecht: Springer.

Kronsell, A., \& Bäckstrand, K. (2010). Rationalities and forms of governance: A framework to analyzing the legitimacy on new modes of governance. In K. Bäckstrand, J. Khan, A. Kronsel \& E. Lövbrand (Eds.), Environmental politics and deliberative democracy. (pp. 28-46). Cheltenham: Edward Elgar Publishing.

Lawless, P., \& Pearson, S. (2012). Outcomes from Community Engagement in Urban Regeneration: Evidence from England's New Deal for Communities Programme. Planning Theory \& Practice, 13(4), 509-527.

Leal, P. A. (2007). Participation: the ascendancy of a buzzword in the neo-liberal era. Development in Practice, 17(4/5), 539-548.

Leino, H. (2012). Boundary Interaction in Emerging Scenes: Two participatory Planning Cases from Finland. Planning Theory \& Practice, 13(3), 383-396.

Leino, H., \& Laine, M. (2012). Do matters of concern matter? Bringing issues back to participation. Planning Theory, 11(1), 89-103.

Lester, W., \& Reckhow, S. (2012). Network governance and regional equity: Shared agendas or problematic partners? Planning Theory, 12(2), 115-138.

Lindblom, C. E. (1959). The science of muddling through, Public Administration Review, 19(2), 79-88.

Lister, R. (2007). Why citizenship: where, when and how children? Theoretical Inquiries in Law, 8(2), 693-718.

Lysgård, H. J., \& Cruickshank, J. (2013). Creating attractive places for whom? A discourse theoretical approach to knowledge and planning. Environment and Planning A, 45, 2868 - 2883.

McLaughlin K., Osborne S.P., \& Ferlies, E. (Eds.). (2002). New Public Management. Current trends and future prospects. London: Routledge.

Miller, P., \& Rose, N. (2008). Governing the Present: Administering the Economic, Social and Personal Life. Cambridge: Polity Press. 
Practice 15:3, 311-327, doi:10.1080/14649357.2014.929726. For citation, please use the original.

Mouffe, C. (2000). The Democratic Paradox. London: Verso.

Mouffe, C. (2013). Agonistics. Thinking the world politically. London: Verso.

Mäntysalo, R., \& Saglie, I-L. (2010). Private Influence Preceding Public Involvement: Strategies for Legitimizing Preliminary Partnership Arrangements in Urban Housing Planning in Norway and Finland. Planning Theory \& Practice, 11(3), 317-338.

Nyman, K. (2000). Maankäyttö- ja rakennuslaki: henki vai kirjain? [The land use and building act: the spirit or the letter?]. Yhteiskuntasuunnittelu 2000:2, 38, 6-16.

Olsson, J., \& Hysing, E. (2012). Theorizing Inside Activism: Understanding Policymaking and Policy Change from Below. Planning Theory \& Practice, 13(2), 257-273.

Portugali, J. (2008). Learning from paradoxes about prediction and planning in selforganizing cities. Planning Theory, 7(3), 248-261.

Puustinen, S. (2006). Suomalainen kaavoittajaprofessio ja suunnittelun kommunikatiivinen käänne. Vuorovaikutukseen liittyvät ongelmat ja mahdollisuudet suurten kaupunkien kaavoittajien näkökulmasta [The Finnish planner profession and the communicative turn in planning: the problems and possibilities from the point of view of the planners of the large cities].

Yhdyskuntasuunnittelun tutkimus- ja koulutuskeskuksen julkaisuja A34. Espoo: Teknillinen korkeakoulu.

Rosanvallon, P. (2008). Counter-Democracy: Politics in an Age of Distrust. (A. Goldhammer, trans.) Cambridge: Cambridge University Press.

Sager, T. (1994). Communicative Planning Theory. Aldershot: Avebury.

Sager, T. (2009). Planners' role: Torn between dialogical ideals and neo-liberal realities. European Planning Studies, 17(1), 65-84.

Sager, T. (2012). Adapting planners’ professionalism for inclusive processes in neo-liberal environments. Town Planning Review, 83 (5), 619-623. Sam, M.P., \& Scherer, J. (2006). The steering group as policy advice instrument: A case of “consultocracy” in stadium subsidy deliberations. Policy Science, 39, 169-181.

Schulman, H. (1990). Alueelliset todellisuudet ja visiot: Helsingin kehitys ja kehittäminen 1900-luvulla. [Regional realities and visions: Development of 
and developing in Helsinki in the 20th century]. Yhdyskuntasuunnittelun tutkimus- ja koulutuskeskuksen julkaisuja, A 18. Espoo: Teknillinen korkeakoulu.

Silver, H., Scott, A., \& Kazepov, Y. (2010). Participation in Urban Contention and Deliberation. International Journal of urban and Regional Research, 34(3), 453477.

Skelcher C., \& Torfing, J. (2010). Improving democratic governance through institutional design: Civic participation and democratic ownership in Europe. Regulation and Governance, 4(1), 71-91.

Staeheli, L. (2011). Political geography: where’s citizenship? Progress in Human Geography, 35(3), 393-400.

Stenvall, J. (2000). Käskyläisestä toimijaksi: Valtion keskushallinnon virkamiehistön pätevyyden arvostusten kehitys suuriruhtinaskunnan ajan alusta 2000-luvulle. [From subordinate to initiator: Development of the esteem of central administration officials' competence from the early days of Finnish grand duchy to the 21st century]. Acta Universitatis Tamperensis 759. Tampere: Tampereen yliopisto.

Taylor, N. (1998). Urban Planning Theory Since 1945. London: Sage.

Torfing, J., Sørensen, E., \& Fotel, T. (2009). Democratic Anchorage of Infrastructural Governance Networks: the case of the Femern Belt Forum. Planning Theory, 8(3), 282-308.

Yetano, A., Royo, S., \& Acerete, B. (2010). What is driving the increasing presence of citizen participation initiatives? Environment and Planning C: Government and Policy, 28(5), 783-802.

Wagenaar, H., Cook, S., \& Noam, D. (2003). Understanding policy practices: action, dialectic and deliberation in policy analysis. In Hajer, Maarten A. \& Wagenaar, Hendrik (eds.) Deliberative Policy Analysis. Understanding Governance in the Network Society. (pp. 139-171). Cambridge: Cambridge University Press.

Wagenaar H. (2011). Meaning in action. Interpretation and dialogue in policy analysis. New York: M. E. Sharpe. 
Practice 15:3, 311-327, doi:10.1080/14649357.2014.929726. For citation, please use the original. 